\title{
Stable carbon isotope fractionation of organic cyst-forming dinoflagellates: Evaluating the potential for a $\mathrm{CO}_{2}$ proxy
}

\author{
Mirja Hoins ${ }^{\mathrm{a}, \mathrm{b}, *}$, Dedmer B. Van de Waal $^{\mathrm{c}}$, Tim Eberlein ${ }^{\mathrm{b}}$, Gert-Jan Reichart ${ }^{\mathrm{a}, \mathrm{d}}$, \\ Björn Rost ${ }^{\mathrm{b}}$, Appy Sluijs ${ }^{\mathrm{a}}$ \\ ${ }^{a}$ Department of Earth Sciences, Faculty of Geosciences, Utrecht University, Budapestlaan 4, 3584 CD Utrecht, The Netherlands \\ ${ }^{\mathrm{b}}$ Marine Biogeosciences, Alfred Wegener Institute, Helmholtz Centre for Polar and Marine Research, Am Handelshafen 12, 27570 \\ Bremerhaven, Germany \\ ${ }^{\mathrm{c}}$ Department of Aquatic Ecology, Netherlands Institute of Ecology (NIOO-KNAW), Droevendaalsesteeg 10, 6708 PB Wageningen, \\ The Netherlands \\ ${ }^{\mathrm{d}}$ Royal Netherlands Institute for Sea Research (NIOZ), Landsdiep 4, 1797 SZ 't Horntje, Texel, The Netherlands
}

Received 5 May 2014; accepted in revised form 1 April 2015; available online 9 April 2015

\begin{abstract}
Over the past decades, significant progress has been made regarding the quantification and mechanistic understanding of stable carbon isotope fractionation $\left({ }^{13} \mathrm{C}\right.$ fractionation) in photosynthetic unicellular organisms in response to changes in the partial pressure of atmospheric $\mathrm{CO}_{2}\left(p \mathrm{CO}_{2}\right)$. However, hardly any data is available for organic cyst-forming dinoflagellates while this is an ecologically important group with a unique fossil record. We performed dilute batch experiments with four harmful dinoflagellate species known for their ability to form organic cysts: Alexandrium tamarense, Scrippsiella trochoidea, Gonyaulax spinifera and Protoceratium reticulatum. Cells were grown at a range of dissolved $\mathrm{CO}_{2}$ concentrations characterizing past, modern and projected future values $\left(\sim 5-50 \mu \mathrm{mol} \mathrm{L}^{-1}\right)$, representing atmospheric $p \mathrm{CO}_{2}$ of $180,380,800$ and $1200 \mu \mathrm{atm}$. In all tested species, ${ }^{13} \mathrm{C}$ fractionation depends on $\mathrm{CO}_{2}$ with a slope of up to $0.17 \%$ ( $\mu$ mol L) $)^{-1}$. Even more consistent correlations were found between ${ }^{13} \mathrm{C}$ fractionation and the combined effects of particulate organic carbon quota (POC quota; pg C cell ${ }^{-1}$ ) and $\mathrm{CO}_{2}$. Carbon isotope fractionation as well as its response to $\mathrm{CO}_{2}$ is species-specific. These results may be interpreted as a first step towards a proxy for past $p \mathrm{CO}_{2}$ based on carbon isotope ratios of fossil organic dinoflagellate cysts. However, additional culture experiments focusing on environmental variables other than $p \mathrm{CO}_{2}$, physiological underpinning of the recorded response, testing for possible offsets in ${ }^{13} \mathrm{C}$ values between cells and cysts, as well as field calibration studies are required to establish a reliable proxy.
\end{abstract}

(C) 2015 Elsevier Ltd. All rights reserved.

\section{INTRODUCTION}

Over the past decades, many studies have shown that stable carbon isotope fractionation $\left({ }^{13} \mathrm{C}\right.$ fractionation) in

\footnotetext{
* Corresponding author at: Department of Earth Sciences, Faculty of Geosciences, Utrecht University, Budapestlaan 4, 3584 CD Utrecht, The Netherlands. Tel.: +49 (0) 47148311837.

E-mail address: M.Hoins@uu.nl (M. Hoins).
}

marine unicellular autotrophs varies as a function of dissolved $\mathrm{CO}_{2}$ concentrations (e.g. Degens et al., 1968; Hinga et al., 1994; Pagani, 2014). This work, carried out on species of e.g. cyanobacteria (Eichner et al., 2014), coccolithophores (Pagani et al., 2002; Pagani, 2002), diatoms (Laws et al., 1997) and dinoflagellates (Burkhardt et al., 1999a; Rost et al., 2006), generally shows an increase in ${ }^{13} \mathrm{C}$ fractionation with higher $\mathrm{CO}_{2}$ concentrations. The observed $\mathrm{CO}_{2}$ responses are, however, clearly species-specific. 
The dominant physiological forcing factor of the $\mathrm{CO}_{2}$-dependent ${ }^{13} \mathrm{C}$ fractionation in primary producers is the kinetic fractionation by the carbon-fixing enzyme RubisCO (e.g. Raven and Johnston, 1991). Experiments based on RubisCO isolated from higher plants indicated values of $26-30 \%$ (e.g. Christeller et al., 1976; Roeske and O'Leary, 1984; McNevin et al., 2007). This is somewhat higher than estimates for RubisCO in marine phytoplankton that yields values of $\sim 24 \%$ o (e.g. Roeske and O'Leary, 1985; Guy et al., 1993; Scott et al., 2007). A recent study on the coccolithophore Emiliania huxleyi found a surprisingly low fractionation value of $11 \%$ (Boller et al., 2011), which might lead to re-evaluation of ${ }^{13} \mathrm{C}$ data from various (geo)biological fields. Along with the RubisCO type, ${ }^{13} \mathrm{C}$ fractionation is influenced by the relative uptake of $\mathrm{CO}_{2}$ and $\mathrm{HCO}_{3}^{-}$(Sharkey and Berry, 1985) as the equilibrium discrimination between these carbon species is $\sim 10 \%$ o (Mook et al., 1974). Furthermore, the amount of $\mathrm{CO}_{2}$ that is leaking out of the cell in relation to total inorganic carbon uptake impacts ${ }^{13} \mathrm{C}$ fractionation (Sharkey and Berry, 1985). More specifically, ${ }^{13} \mathrm{C}$ fractionation is high with high leakage because the intracellular ${ }^{12} \mathrm{C}$ pool is replenished at a higher rate.

The ${ }^{13} \mathrm{C}$ fractionation of autotrophic dinoflagellates, abundant eukaryotic unicellular algae, has been shown to vary with $\mathrm{CO}_{2}$. For instance, based on culturing experiments, Burkhardt et al. (1999a) investigated the effects of growth rate, $\mathrm{CO}_{2}$ and cell size on ${ }^{13} \mathrm{C}$ fractionation in one dinoflagellate species and found a clear $\mathrm{CO}_{2}$-sensitivity. Similarly, $\mathrm{CO}_{2}$ dependent ${ }^{13} \mathrm{C}$ fractionation has been found in other both non-calcareous (Rost et al., 2006) and calcareous dinoflagellate species (Van de Waal et al., 2013). It has furthermore been shown that dinoflagellates possess effective carbon concentrating mechanisms (CCMs), including active uptake of both $\mathrm{CO}_{2}$ and $\mathrm{HCO}_{3}^{-}$. The regulations of these $\mathrm{CCMs}$ were shown to be $\mathrm{CO}_{2}$ sensitive (Rost et al., 2006; Eberlein et al., 2014), which may have consequences for ${ }^{13} \mathrm{C}$ fractionation.

Here, we aim to evaluate how ${ }^{13} \mathrm{C}$ fractionation compares between dinoflagellate species. In addition, we quantify the dependency of ${ }^{13} \mathrm{C}$ fractionation to $\mathrm{CO}_{2}$ concentrations ranging from those prevailing during the last glacial $(180 \mu \mathrm{atm})$ to those projected for the end of the next century $(\sim 1200 \mu \mathrm{atm})$. We performed dilute batch culture experiments with Alexandrium tamarense, Scrippsiella trochoidea, Gonyaulax spinifera and Protoceratium reticulatum and show that these species exhibit a clear, yet specific ${ }^{13} \mathrm{C}$ fractionation response to $\mathrm{CO}_{2}$. Notably, these dinoflagellate species produce cysts (dinocysts) as part of their life cycle. The organic dinocysts of $G$. spinifera and P. reticulatum (Spiniferites ramosus and Operculodinium centrocarpum) are recorded ubiquitously in sediments down to the early Cretaceous $(\sim 144-65 \mathrm{Ma} \mathrm{BP})$ and early Cenozoic ( $\sim 65 \mathrm{Ma} \mathrm{BP})$, respectively. Such $\mathrm{CO}_{2}$-dependent changes in ${ }^{13} \mathrm{C}$ fractionation may therefore be a first step in the development of a $\mathrm{CO}_{2}$ proxy based on cyst-producing dinoflagellate species.

\section{MATERIAL AND METHODS}

\subsection{Experimental setup}

Cultures of $A$. tamarense (strain Alex5; Tillmann et al., 2009), S. trochoidea (strain GeoB267), G. spinifera (strain
CCMP 409) and P. reticulatum (strain CCMP 1889), were grown as dilute batch cultures in $2.4 \mathrm{~L}$ air tight borosilicate bottles at a constant temperature of $15^{\circ} \mathrm{C}$. Bottles were pre-aerated with air containing $\mathrm{pCO}_{2}$ representing approximations of the Last Glacial Maximum (180 $\mu \mathrm{atm})$, present-day $(380 \mu \mathrm{atm})$, and distant past levels that could be considered future scenarios as well (800 and $1200 \mu \mathrm{atm})$, representing a range of dissolved $\mathrm{CO}_{2}$ concentrations of $\sim 5-50 \mu \mathrm{mol} \mathrm{L}^{-1}$. These levels were obtained by mixing $\mathrm{CO}_{2}$-free air $\left(<0.1 \mu \mathrm{atm} \quad p \mathrm{CO}_{2}\right.$, Domnick Hunter, Willrich, Germany) with pure $\mathrm{CO}_{2}$ (Air liquide Deutschland, Düsseldorf, Germany) using mass flow controllers (CGM 2000, MCZ Umwelttechnik, Bad Nauheim, Germany). Each $p \mathrm{CO}_{2}$ treatment was performed in triplicate. Experiments were carried out at low cell densities with a final concentration of up to 400 cells $\mathrm{mL}^{-1}$ in order to assure that changes in carbonate chemistry remained low (i.e. $<3.5 \%$ with respect to dissolved inorganic carbon; DIC). Cultures were grown at a salinity of 34 in filtered North Sea water (cellulose acetate membrane, $0.2 \mu \mathrm{m}$ pore size, Sartorius, Göttingen, Germany), enriched with $100 \mu \mathrm{mol} \mathrm{L}^{-1}$ nitrate and $6.25 \mu \mathrm{mol} \mathrm{L}^{-1}$ phosphate. Metals and vitamins were added according to $\mathrm{f} / 2$ medium (Guillard and Ryther, 1962), except for $\mathrm{FeCl}_{3}$ $\left(1.9 \mu \mathrm{mol} \mathrm{L}^{-1}\right), \quad \mathrm{H}_{2} \mathrm{SeO}_{3} \quad\left(10 \mathrm{nmol} \mathrm{L}^{-1}\right) \quad$ and $\mathrm{NiCl}_{2}$ $\left(6.3 \mathrm{nmol} \mathrm{L}^{-1}\right)$ that were added according to $\mathrm{K}$ medium (Keller et al., 1987). To avoid sedimentation and aggregation, bottles were placed on a roller table. Daylight tubes (Lumilux HO 54 W/965, Osram, München, Germany) installed above the roller table provided an incident light intensity of $250 \pm 25 \mu \mathrm{mol}$ photons $\mathrm{m}^{-2} \mathrm{~s}^{-1}$ at a $16: 8 \mathrm{~h}$ light:dark cycle.

\subsection{Sampling and analyses}

To monitor changes in the carbonate chemistry of each of the four tested $p \mathrm{CO}_{2}$ treatments, $\mathrm{pH}$ was measured every other day using a WTW $3110 \mathrm{pH}$ meter equipped with a SenTix 41 Plus pH electrode (Wissenschaftlich-Technische Werkstätten GmbH, Weilheim, Germany), which was calibrated prior to each measurement on the National Bureau of Standards (NBS) scale. To measure total alkalinity (TA), samples of $50 \mathrm{~mL}$ culture suspension were filtered over cellulose acetate syringe filters (Thermo Scientific, $0.2 \mu \mathrm{m}$ pore size) and stored in gas tight borosilicate bottles at $3{ }^{\circ} \mathrm{C}$. Samples were then analyzed in duplicates using an automated TitroLine burette system (SI Analytics, Mainz, Germany). For colorimetric analysis of DIC, $4 \mathrm{~mL}$ of cell suspension was filtered over a $0.2 \mu \mathrm{m}$ cellulose acetate filter and stored in headspace free gas tight borosilicate bottles at $3{ }^{\circ} \mathrm{C}$. Samples were measured in duplicates using a QuAAtro autoanalyser (Seal Analytical, Mequon, USA). Both TA and DIC were measured at the beginning and the end of each experiment to ensure together with $\mathrm{pH}$ measurements a complete resolution of the carbonate chemistry. The carbonate chemistry was assessed with the program CO2sys (Lewis and Wallace, 2006), using TA and $\mathrm{pH}$ (average values of beginning and end of each experiment), temperature, salinity and phosphate concentration. The dissociation constants of carbonic acid and sulfuric 
acid were based on Mehrbach et al. (1973), refit by Dickson and Millero (1987) and Dickson (1990), respectively.

Cells were acclimated to the $p \mathrm{CO}_{2}$ treatments for at least 7 generations (i.e. $>21$ days) prior to each experiment. Duplicate samples of $1-20 \mathrm{~mL}$ culture suspension were fixed with neutral Lugol's solution ( $2 \%$ final concentration in MilliQ) and counted every day or every other day with an inverted light microscope (Axiovert 40C, Zeiss, Germany). Growth rates $\left(\mu ; \mathrm{d}^{-1}\right)$ were assessed separately for each biological treatment by fitting an exponential function through the cell numbers over time according to:

$\mathrm{B}=\mathrm{B}_{0} \mathrm{e}^{\mu \mathrm{t}}$

with $\mathrm{B}$ referring to cell number at time $\mathrm{t}, \mathrm{B}_{0}$ to the cell number at the start of the experiment, and $\mu$ referring to the specific growth rate. Particulate organic carbon (POC) production $\left(\mu_{\mathrm{c}} ; \mathrm{pg} \mathrm{C} \mathrm{cell}^{-1} \mathrm{day}^{-1}\right.$ ) is calculated by multiplying growth rate with POC quota (pg Cell ${ }^{-1}$ ).

To measure POC and its carbon isotopic composition $\left(\delta^{13} \mathrm{C}_{\mathrm{POC}}\right), 300-400 \mathrm{~mL}$ of culture suspension was filtered over precombusted $\mathrm{GF} / \mathrm{F}$ filters $\left(6 \mathrm{~h}, 500^{\circ} \mathrm{C}\right)$. Filters were stored in pre-combusted glass Petri dishes and $200 \mu \mathrm{L}$ of $\mathrm{HCl}\left(0.1 \mathrm{~mol} \mathrm{~L}^{-1}\right)$ was added to remove the inorganic carbon before they were dried overnight and stored at $-25^{\circ} \mathrm{C}$. POC and $\delta^{13} \mathrm{C}_{\mathrm{POC}}$ were then measured in duplicate samples with an Automated Nitrogen Carbon Analyser mass spectrometer (ANCA-SL 20-20, SerCon Ltd., Crewe, UK), with a precision of $\pm 0.5 \mu \mathrm{g} \mathrm{C}$ and $0.3 \%$, respectively. $\delta^{13} \mathrm{C}_{\mathrm{POC}}$ is reported relative to the Vienna PeeDee Belemnite standard (VPDB). For isotopic measurements of the dissolved inorganic carbon $\left(\delta^{13} \mathrm{C}_{\text {DIC }}\right), 4 \mathrm{~mL}$ of culture suspension was sterile filtered over $0.2 \mu \mathrm{m}$ cellulose acetate filters and stored at $3{ }^{\circ} \mathrm{C} .0 .7 \mathrm{~mL}$ of the filtrate was then transferred to $8 \mathrm{~mL}$ vials containing three drops of $102 \% \mathrm{H}_{3} \mathrm{PO}_{4}$ solution and headspaces filled with helium. After equilibration, the isotopic composition in the headspace was measured using a GasBench-II coupled to a Thermo Delta-V advantage isotope ratio mass spectrometer, with a precision of $<0.1 \%$.

\section{3. ${ }^{13} \mathrm{C}$ fractionation}

A mass balance relation following Zeebe and WolfGladrow (2001) was used to calculate $\delta^{13} \mathrm{C}_{\mathrm{CO}_{2}}$ from $\delta^{13} \mathrm{C}_{\text {DIC }}$. Fractionation factors between $\mathrm{CO}_{2}$ and $\mathrm{HCO}_{3}^{-}$ and between $\mathrm{HCO}_{3}^{-}$and $\mathrm{CO}_{3}^{-}$were applied according to Mook et al. (1974) and Zhang et al. (1995), respectively. The isotopic fractionation during POC buildup, $\varepsilon_{\mathrm{pCO}_{2}}$, was calculated relative to the isotopic composition of dissolved $\mathrm{CO}_{2}$ in the water $\left(\delta^{13} \mathrm{C}_{\mathrm{CO}_{2}}\right)$ according to Freeman and Hayes (1992):

$\varepsilon_{\mathrm{pCO}_{2}}=\frac{\delta^{13} \mathrm{C}_{\mathrm{CO}_{2}}-\delta^{13} \mathrm{C}_{\mathrm{POC}}}{1+\frac{\delta^{13} \mathrm{C}_{\mathrm{POC}}}{1000}}$

Because dinoflagellates take up both $\mathrm{HCO}_{3}^{-}$and $\mathrm{CO}_{2}$, the isotopic fractionation during buildup was also calculated based on the isotopic composition of all inorganic carbon species in the growth medium (i.e. $\left[\mathrm{CO}_{2}\right]_{\mathrm{aq}},\left[\mathrm{HCO}_{3}^{-}\right]_{\mathrm{aq}}$, $\left.\left[\mathrm{CO}_{2}^{3-}\right]_{\mathrm{aq}},\left[\mathrm{H}_{2} \mathrm{CO}_{3}\right]_{\mathrm{aq}}\right)$, here called $\varepsilon_{\mathrm{pDIC}}$, according to:
$\varepsilon_{\mathrm{pDIC}}=\frac{\delta^{13} \mathrm{C}_{\mathrm{DIC}}-\delta^{13} \mathrm{C}_{\mathrm{POC}}}{1+\frac{\delta^{13} \mathrm{C}_{\mathrm{POC}}}{1000}}$

\subsection{Statistical analysis}

Holm-Sidak tests confirmed normality of the data. Linear and hyperbolic regressions were used to determine the significance between the tested variables and $\mathrm{CO}_{2}$. Significant differences between $p \mathrm{CO}_{2}$ treatments were confirmed by one-way ANOVA followed by post hoc comparison of the means using the Tukey HSD $(\alpha=0.05$; Table 1$)$. Significances of relationships between ${ }^{13} \mathrm{C}$ fractionation and $\mathrm{CO}_{2}$ were tested by means of linear regression and significances of relationships between ${ }^{13} \mathrm{C}$ fractionation and POC quota/ $\mathrm{CO}_{2}$ and $\mu_{\mathrm{c}} / \mathrm{CO}_{2}$ were tested by means of hyperbolic regression. Analytical errors were calculated using the law of combination of errors (e.g. Barlow, 1989) and approximate $3 \%, 5 \%, 6 \%$ and $8 \%$ for ${ }^{13} \mathrm{C}$ fractionation, $\mathrm{CO}_{2}$ concentration, POC quota/ $\mathrm{CO}_{2}$ and $\mu_{\mathrm{c}} / \mathrm{CO}_{2}$, respectively.

\section{RESULTS}

\subsection{Growth parameters as a function of $\mathrm{CO}_{2}$}

Growth rates, POC quotas and POC production varied between the tested species and were largely independent of $\mathrm{CO}_{2}$ for $A$. tamarense and $P$. reticulatum. Although growth rates remained unaltered over the applied $\mathrm{CO}_{2}$ range in $S$. trochoidea, significantly decreasing POC quotas resulted in decreasing POC production (linear regression; $P<0.05$ ). Growth rates, POC quotas and POC production of the three lower $p \mathrm{CO}_{2}$ treatments of $G$. spinifera did not vary significantly. Growth rates of the $1200 \mathrm{pCO}_{2}$ treatment, however, were significantly lower and POC quotas significantly higher compared to the other $p \mathrm{CO}_{2}$ treatments, resulting in a significantly increased $\mathrm{POC}$ production (ANOVA; $P<0.05$; Table 1 ). Note that $\mathrm{CO}_{2}$ concentrations of specific $p \mathrm{CO}_{2}$ treatments tend to have higher variations under elevated $p \mathrm{CO}_{2}$, primarily due to the lowered buffering capacity under these conditions (Egleston et al., 2010). Effective $\mathrm{CO}_{2}$ concentrations nonetheless always differed significantly between the treatments for each tested species (ANOVA; $P<0.05$; Table 1).

\subsection{Carbon isotopic fractionation}

${ }^{13} \mathrm{C}$ fractionation $\left(\varepsilon_{\mathrm{pCO}_{2}}\right.$ and $\left.\varepsilon_{\mathrm{pDIC}}\right)$ of all tested species, except for $G$. spinifera, show significant positive correlations with $\mathrm{CO}_{2}$ over the whole range of applied $\mathrm{CO}_{2}$ concentrations $(P<0.05$; Fig. 1). Slopes of the linear relationship range from $0.05 \%$ to $0.16 \%$ o $\left(\mu \mathrm{mol} \mathrm{CO} \mathrm{CO}_{2} \mathrm{~L}\right)^{-1}$ in A. tamarense, $S$. trochoidea and $P$. reticulatum. ${ }^{13} \mathrm{C}$ fractionation of $G$. spinifera is clearly $\mathrm{CO}_{2}$-dependent in the three lower $p \mathrm{CO}_{2}$ treatments (Fig. 1c). Since the ${ }^{13} \mathrm{C}$ fractionation in the highest $p \mathrm{CO}_{2}$ treatment is very low, however, no linear relationship can be obtained over the entire $\mathrm{CO}_{2}$ range tested. We found no significant linear relationship between ${ }^{13} \mathrm{C}$ fractionation and growth rate, POC 
Table 1

Experimental conditions, growth parameters and ${ }^{13} \mathrm{C}$ fractionation in dilute batch culture incubations: Average dissolved $\mathrm{CO}_{2}$ concentration $\left(\mu \mathrm{mol} \mathrm{L}{ }^{-1}\right)$, growth rate $\left(\mu, \mathrm{d}^{-1}\right)$, POC quota $\left(\mathrm{pg} \mathrm{C}\right.$ cell $\left.{ }^{-1}\right)$, POC production $\left(\mu_{\mathrm{c}}, \mathrm{pg} \mathrm{C}\right.$ cell $\left.^{-1} \mathrm{~d}^{-1}\right),{ }^{13} \mathrm{C}$ fractionation $\varepsilon_{\mathrm{pCO}}(\%)$ based on $\delta^{13} \mathrm{C}_{\mathrm{CO}_{2}}$ and ${ }^{13} \mathrm{C}$ fractionation $\varepsilon_{\mathrm{pDIC}}(\%)$ based on $\delta^{13} \mathrm{C}_{\mathrm{DIC}}$. Values represent the mean of triplicate incubations $(n=3, \pm \mathrm{SD})$. Significant differences between $p \mathrm{CO}_{2}$ treatments are indicated by superscript letters.

\begin{tabular}{|c|c|c|c|c|c|c|}
\hline $\begin{array}{c}p \mathrm{CO}_{2} \text { treatments } \\
(\mu \mathrm{atm})\end{array}$ & $\mathrm{CO}_{2}\left(\mu \mathrm{mol} \mathrm{L}^{-1}\right)$ & $\mu\left(d^{-1}\right)$ & $\begin{array}{l}\text { POC quota } \\
\left(\text { pg C cell }{ }^{-1}\right)\end{array}$ & $\begin{array}{c}\mu_{\mathrm{c}} \\
\left(\mathrm{pg} \mathrm{C} \text { cell }^{-1} \mathrm{~d}^{-1}\right)\end{array}$ & $\varepsilon_{\mathrm{pCO}_{2}}(\%)$ & $\varepsilon_{\mathrm{pDIC}}(\%)$ \\
\hline \multicolumn{7}{|l|}{ A. tamarense } \\
\hline 180 & $5.92 \pm 0.90^{\mathrm{a}}$ & $0.46 \pm 0.02^{\mathrm{a}, \mathrm{b}}$ & $3169 \pm 254$ & $1466 \pm 76$ & $9.01 \pm 0.29^{\mathrm{a}}$ & $19.25 \pm 0.29^{\mathrm{a}}$ \\
\hline 380 & $11.53 \pm 2.09^{b}$ & $0.46 \pm 0.02^{\mathrm{a}, \mathrm{b}}$ & $3620 \pm 308$ & $1676 \pm 117$ & $10.24 \pm 0.46^{\mathrm{b}}$ & $20.64 \pm 0.47^{\mathrm{b}}$ \\
\hline 800 & $25.89 \pm 5.64^{\mathrm{c}}$ & $0.48 \pm 0.01^{\mathrm{a}}$ & $3455 \pm 153$ & $1669 \pm 55$ & $12.72 \pm 0.44^{\mathrm{c}}$ & $23.13 \pm 0.45^{\mathrm{c}}$ \\
\hline 1200 & $36.46 \pm 9.09^{\mathrm{d}}$ & $0.45 \pm 0.01^{\mathrm{b}}$ & $3461 \pm 165$ & $1545 \pm 61$ & $12.12 \pm 0.16^{\mathrm{c}}$ & $22.56 \pm 0.16^{\mathrm{c}}$ \\
\hline \multicolumn{7}{|l|}{ S. trochoidea } \\
\hline 180 & $6.62 \pm 0.21^{\mathrm{a}}$ & $0.61 \pm 0.03$ & $1990 \pm 36^{\mathrm{a}}$ & $1208 \pm 40^{\mathrm{a}}$ & $6.03 \pm 0.51^{\mathrm{a}, \mathrm{b}}$ & $16.26 \pm 0.51^{\mathrm{a}, \mathrm{b}}$ \\
\hline 380 & $13.13 \pm 0.54^{\mathrm{b}}$ & $0.61 \pm 0.05$ & $1762 \pm 15^{\mathrm{a}, \mathrm{b}}$ & $1080 \pm 77^{\mathrm{a}, \mathrm{b}}$ & $5.03 \pm 0.11^{\mathrm{a}}$ & $15.81 \pm 0.11^{\mathrm{a}}$ \\
\hline 800 & $28.77 \pm 2.03^{\mathrm{c}}$ & $0.61 \pm 0.04$ & $1787 \pm 223^{\mathrm{a}, \mathrm{b}}$ & $1097 \pm 135^{\mathrm{a}, \mathrm{b}}$ & $7.10 \pm 0.67^{\mathrm{b}}$ & $17.50 \pm 0.68^{b}$ \\
\hline 1200 & $41.51 \pm 3.56^{\mathrm{d}}$ & $0.58 \pm 0.02$ & $1500 \pm 85^{\mathrm{b}}$ & $874 \pm 24^{\mathrm{b}}$ & $11.67 \pm 0.68^{\mathrm{c}}$ & $22.19 \pm 0.69^{c}$ \\
\hline \multicolumn{7}{|l|}{ G. spinifera } \\
\hline 180 & $6.01 \pm 1.11^{\mathrm{a}}$ & $0.22 \pm 0.02^{\mathrm{a}}$ & $3708 \pm 366^{\mathrm{a}}$ & $812 \pm 21^{\mathrm{a}}$ & $7.79 \pm 1.03^{\mathrm{a}}$ & $18.14 \pm 0.99^{\mathrm{a}}$ \\
\hline 380 & $11.73 \pm 2.54^{\mathrm{b}}$ & $0.23 \pm 0.01^{\mathrm{a}}$ & $2758 \pm 583^{\mathrm{a}}$ & $637 \pm 150^{\mathrm{a}}$ & $9.44 \pm 0.41^{\mathrm{a}}$ & $19.86 \pm 0.41^{\mathrm{a}}$ \\
\hline 800 & $27.91 \pm 7.4^{\mathrm{c}}$ & $0.23 \pm 0.04^{\mathrm{a}}$ & $3521 \pm 263^{\mathrm{a}}$ & $782 \pm 159^{\mathrm{a}}$ & $11.74 \pm 0.67^{\mathrm{b}}$ & $22.15 \pm 1.12^{\mathrm{b}}$ \\
\hline 1200 & $42.36 \pm 7.88^{\mathrm{d}}$ & $0.15 \pm 0.01^{\mathrm{b}}$ & $8842 \pm 1044^{\mathrm{b}}$ & $1321 \pm 101^{\mathrm{b}}$ & $8.02 \pm 0.46^{\mathrm{a}}$ & $18.43 \pm 0.47^{\mathrm{a}}$ \\
\hline \multicolumn{7}{|l|}{ P. reticulatum } \\
\hline 180 & $7.05 \pm 0.48^{\mathrm{a}}$ & $0.28 \pm 0.00$ & $3099 \pm 119^{\mathrm{a}}$ & $859 \pm 44^{\mathrm{a}}$ & $8.37 \pm 1.82$ & $18.78 \pm 1.77$ \\
\hline 380 & $13.87 \pm 0.78^{\mathrm{b}}$ & $0.28 \pm 0.01$ & $2494 \pm 356^{\mathrm{a}, \mathrm{b}}$ & $699 \pm 149^{\mathrm{a}, \mathrm{b}}$ & $8.43 \pm 0.69$ & $18.88 \pm 0.67$ \\
\hline 800 & $31.02 \pm 4.7^{\mathrm{c}}$ & $0.29 \pm 0.02$ & $2351 \pm 694^{\mathrm{b}}$ & $676 \pm 215^{a, b}$ & $8.56 \pm 2.29$ & $20.32 \pm 0.02$ \\
\hline 1200 & $45.20 \pm 6.85^{\mathrm{d}}$ & $0.29 \pm 0.03$ & $2600 \pm 316^{\mathrm{a}, \mathrm{b}}$ & $736 \pm 23^{\mathrm{b}}$ & $9.88 \pm 0.81$ & $20.27 \pm 0.80$ \\
\hline
\end{tabular}

quota or POC production, except for $S$. trochoidea, for which ${ }^{13} \mathrm{C}$ fractionation is correlated to both POC quota and POC production (linear regression; $P<0.05$; data not shown).

To account for possible combined effects of growth parameters and $\mathrm{CO}_{2}$ on ${ }^{13} \mathrm{C}$ fractionation, we investigated the relationships between ${ }^{13} \mathrm{C}$ fractionation and $\mathrm{POC}$ quota $/ \mathrm{CO}_{2}$ or $\mu_{\mathrm{c}} / \mathrm{CO}_{2}$ (Figs. 2 and 3). In all tested species, significant relationships between ${ }^{13} \mathrm{C}$ fractionation and POC quota/ $/ \mathrm{CO}_{2}$ or $\mu_{\mathrm{c}} / \mathrm{CO}_{2}$ were obtained $(P<0.05$; Figs. 2 and 3). Generally, ${ }^{13} \mathrm{C}$ fractionation is hyperbolically correlated to POC quota/ $\mathrm{CO}_{2}$ or $\mu_{\mathrm{c}} / \mathrm{CO}_{2}$. In $A$. tamarense and $S$. trochoidea, significant hyperbolic correlations were also found between ${ }^{13} \mathrm{C}$ fractionation and $\mu / \mathrm{CO}_{2}$ $(P<0.05$; data not shown $)$.

\section{DISCUSSION}

In this study, we investigated ${ }^{13} \mathrm{C}$ fractionation of four different dinoflagellate species over a wide range of $p \mathrm{CO}_{2}$. With the exception of one treatment in $G$. spinifera, ${ }^{13} \mathrm{C}$ fractionation increased linearly with increasing $\mathrm{CO}_{2}$ levels. Since ${ }^{13} \mathrm{C}$ fractionation may be related to changing growth parameters, we moreover investigated growth rates, POC quotas and POC production. Growth rates, POC quota and POC production differed substantially between the tested species but remained generally unaltered over the tested $\mathrm{CO}_{2}$ range. Highest $\mathrm{CO}_{2}$-dependent sensitivities in ${ }^{13} \mathrm{C}$ fractionation were observed under low POC quota and $\mathrm{POC}$ production (i.e. low carbon demand) in combination with high $\mathrm{CO}_{2}$ concentrations (i.e. high carbon supply).

\section{1. ${ }^{13} \mathrm{C}$ fractionation}

In all tested dinoflagellate species, ${ }^{13} \mathrm{C}$ fractionation is clearly $\mathrm{CO}_{2}$-dependent (Fig. 1). With linear slopes of $0.17 \%$ o $(\mu \mathrm{mol} \mathrm{L})^{-1}$ for $G$. spinifera (for the range 180 $\left.800 \mu \mathrm{atm} \mathrm{CO}_{2}\right)$ and $0.16 \%$ ( $\left.\mu \mathrm{mol} \mathrm{L}\right)^{-1}$ for $S$. trochoidea, $\mathrm{CO}_{2}$ dependency of ${ }^{13} \mathrm{C}$ fractionation was stronger than the steepest of the various slopes observed for the coccolith-bearing, alkenone producing algae E. huxleyi $(\sim 0.13 \%$ $(\mu \mathrm{mol} \mathrm{L})^{-1}$; Riebesell et al., 2000; Rost et al., 2002). In comparison, slopes of $A$. tamarense $\left(0.11 \%(\mu \mathrm{mol} \mathrm{L})^{-1}\right)$ and $P$. reticulatum $\left(0.05 \%(\mu \mathrm{mol} \mathrm{L})^{-1}\right)$ were comparable or lower, respectively. The observed relationships between ${ }^{13} \mathrm{C}$ fractionation and $\mathrm{CO}_{2}$ are strongly species-specific (Fig. 1). This may be the result of differences in growth rates and/or POC production, as observed in various phytoplankton species (Fry and Wainright, 1991; Laws et al., 1995, 1997; Rau et al., 1996; Rost et al., 2002).

Rau et al. (1996) and Popp et al. (1998) proposed species-specific ${ }^{13} \mathrm{C}$ fractionation to be related to cell morphology, which alters the POC quota to surface area ratios. In this study, however, all species have spherical cell geometry with little differences in size; therefore including surface area does not reduce the observed species-specific differences in ${ }^{13} \mathrm{C}$ fractionation.

Including POC quota and POC production, however, indeed improved relationships (i.e. higher $R^{2}$ values for $S$. trochoidea, G. spinifera and P. reticulatum; Figs. 2 and 3), even though significant species-specific differences in $\mathrm{CO}_{2}$ dependent ${ }^{13} \mathrm{C}$ fractionation remain. Crucially, this shows that the low fractionation factor recorded in G. spinifera 


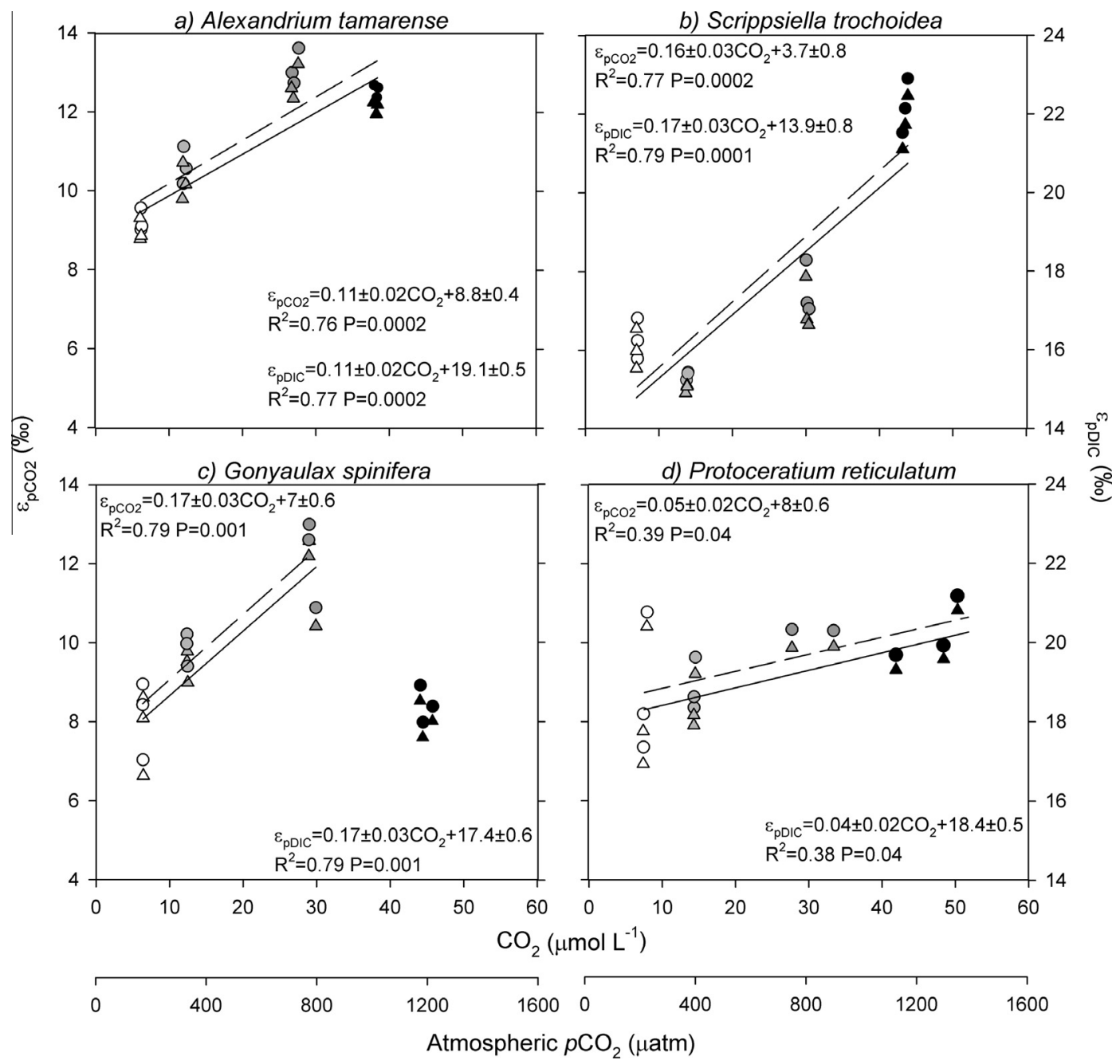

Fig. $1 .{ }^{13} \mathrm{C}$ fractionation based on $\mathrm{CO}_{2}\left(\varepsilon_{\mathrm{pCO}_{2}}\right.$, triangles $)$ and $\mathrm{DIC}\left(\varepsilon_{\mathrm{pDIC}}\right.$, circles $)$ of the studied dinoflagellates as a function of $\mathrm{CO}_{2}$, and the respective linear relationships. The various $p \mathrm{CO}_{2}$ treatments are indicated by open $(180 \mu \mathrm{atm})$, light gray $(380 \mu \mathrm{atm})$, dark gray $(800 \mu \mathrm{atm})$ and black $(1200 \mu \mathrm{atm})$ symbols. The combination of analytical errors approximates $3 \%$ for ${ }^{13} \mathrm{C}$ fractionation and $5 \%$ for $\mathrm{CO}_{2}$. Symbols show biological triplicates for each treatment. For clarity reasons, treatment means and standard deviations are provided in Table 1. Linear trend lines represent relationships between $\varepsilon_{\mathrm{pCO}_{2}}$ and $\mathrm{CO}_{2}$ (solid line) and $\varepsilon_{\mathrm{pDIC}}$ and $\mathrm{CO}_{2}$ (dashed line). Trend lines for G. spinifera represent the 180, 380 and $800 \mu \mathrm{atm} p \mathrm{CO}_{2}$ treatments only. The very low ${ }^{13} \mathrm{C}$ fractionation in the highest $p \mathrm{CO}_{2}$ treatment is most likely due to extraordinarily large cells (high POC quotas; Table 1; see text).

in the $1200 \mu \mathrm{atm} p \mathrm{CO}_{2}$ treatment is in large part related to significantly increased POC quota and decreased growth. Cells in this treatment were observed to be significantly larger, and grew significantly slower, than cells in the 180,380 and $800 \mu \mathrm{atm} p \mathrm{CO}_{2}$ treatments. At present there is no mechanistic explanation for this offset.

The correlations between ${ }^{13} \mathrm{C}$ fractionation and POC quota/ $\mathrm{CO}_{2}$ or $\mu_{\mathrm{c}} / \mathrm{CO}_{2}$ were not linear but hyperbolic, possibly indicating the presence of CCMs in the tested species. CCMs involve different components and processes, of which two can in principle affect ${ }^{13} \mathrm{C}$ fractionation: (1) the acquisition of not only $\mathrm{CO}_{2}$ but also $\mathrm{HCO}_{3}^{-}$through active uptake, and/or (2) changes in the amount of $\mathrm{CO}_{2}$ leaking out of the cell. Since $\mathrm{HCO}_{3}^{-}$is ${ }^{13} \mathrm{C}$-enriched relative to $\mathrm{CO}_{2}$, a decrease in its uptake, e.g. with increasing $\mathrm{CO}_{2}$ concentrations, may increase ${ }^{13} \mathrm{C}$ fractionation. Increasing leakage may also increase ${ }^{13} \mathrm{C}$ fractionation since it replenishes the intracellular inorganic carbon pool and thus decreases the ${ }^{13} \mathrm{C}$ accumulation in the vicinity of RubisCO (Sharkey and Berry, 1985; Francois et al., 1993; Rost et al., 2006). CCMs have been reported to differ between $A$. tamarense, $S$. trochoidea and $P$. reticulatum, with respect to the relative $\mathrm{HCO}_{3}^{-}$uptake and leakage as well as to their $\mathrm{CO}_{2}$-dependent regulation (Rost et al., 2006; Ratti et al., 2007; Eberlein et al., 2014). Further elucidation of the carbon acquisition characteristics of the tested dinoflagellate species will help developing mechanistic models describing $\mathrm{CO}_{2}$-dependent ${ }^{13} \mathrm{C}$ fractionation for potential proxy species.

\subsection{Proxy application outlook}

The $\mathrm{CO}_{2}$ dependency of ${ }^{13} \mathrm{C}$ fractionation in dinoflagellates as described here implies that ${ }^{13} \mathrm{C}$ signatures may potentially be used for the reconstruction of past $\mathrm{CO}_{2}$ concentrations. The experiments indicate that variations in 

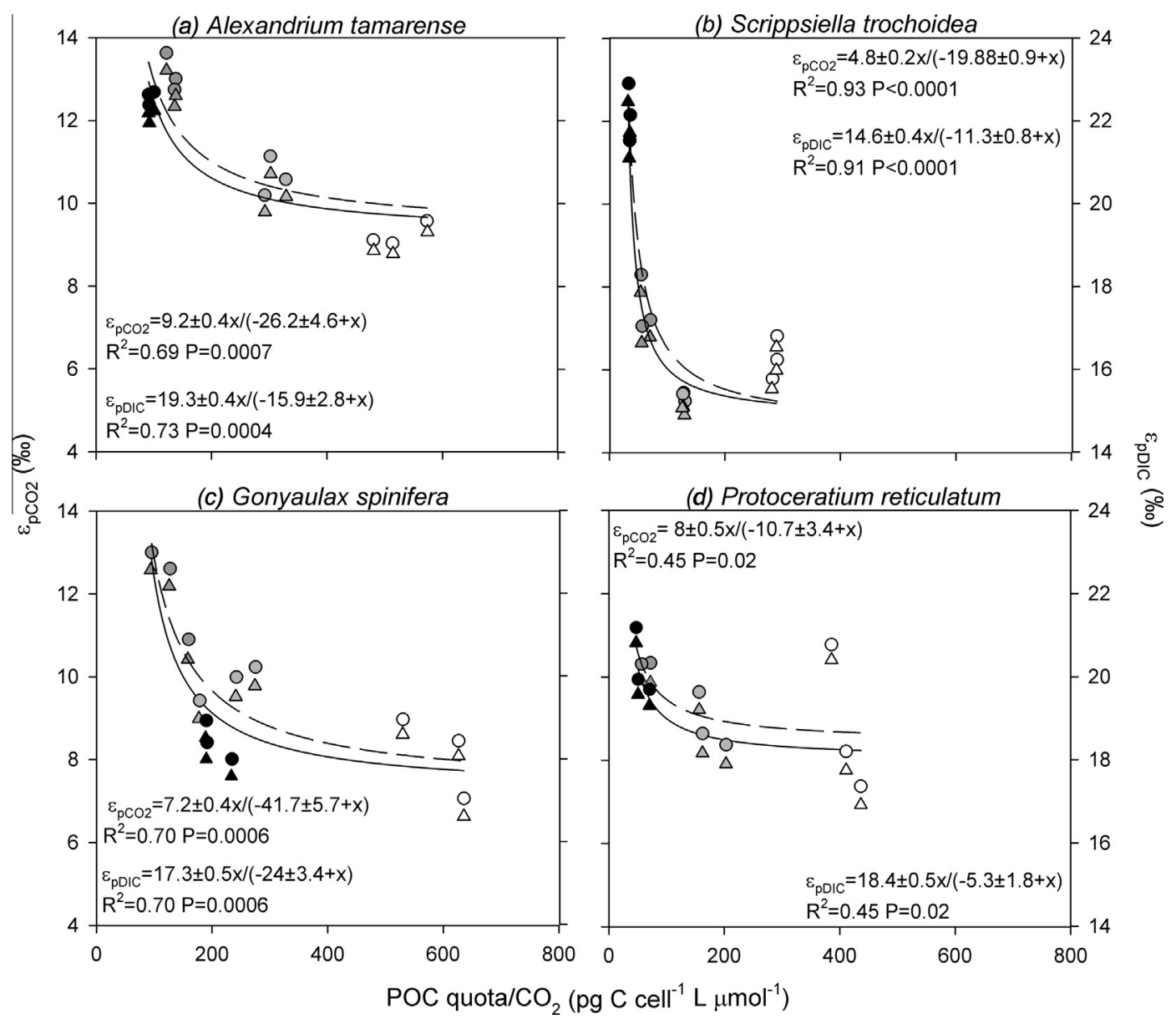

Fig. 2. ${ }^{13} \mathrm{C}$ fractionation based on $\mathrm{CO}_{2}\left(\varepsilon_{\mathrm{pCO}}\right.$, triangles $)$ and DIC ( $\varepsilon_{\mathrm{pDIC}}$, circles) of the studied dinoflagellates as a function of POC quota/ $\mathrm{CO}_{2}$, and the respective hyperbolic relationships. Trend lines represent relationships between $\varepsilon_{\mathrm{pCO}_{2}}$ and $\mathrm{POC}$ quota/CO 2 (solid line) and $\varepsilon_{\mathrm{pDIC}}$ and POC quota $/ \mathrm{CO}_{2}$ (dashed line). Various $p \mathrm{CO}_{2}$ treatments are indicated by open (180 $\left.\mu \mathrm{atm}\right)$, light gray $(380 \mu \mathrm{atm})$, dark gray $(800 \mu \mathrm{atm})$ and black $(1200 \mu \mathrm{atm})$ symbols. The combination of analytical errors approximates $3 \%$ for ${ }^{13} \mathrm{C}$ fractionation and $6 \%$ for $\mathrm{POC} \mathrm{quota} / \mathrm{CO}_{2}$. Symbols show biological triplicates for each treatment. For clarity reasons, treatment means and standard deviations are provided in Table 1.

growth rates and POC quota and/or POC production may affect ${ }^{13} \mathrm{C}$ fractionation. However, G. spinifera is the only species that showed strong $\mathrm{CO}_{2}$-dependent changes in these parameters (Table 1). Crucially, ${ }^{13} \mathrm{C}$ fractionation in G. spinifera correlates best to $\mathrm{POC}$ quota/ $\mathrm{CO}_{2}$ (Fig. 2c), rather than $\mu_{\mathrm{c}} / \mathrm{CO}_{2}$ (Fig. 3c), indicating a stronger effect of POC quota on ${ }^{13} \mathrm{C}$ fractionation than growth rates. While growth rates are difficult to constrain for paleoreconstructions (Eppley, 1972; Popp et al., 1997), POC quota may be estimated based on cyst size. For instance, MendenDeuer and Lessard (2000) reviewed previous and own data to infer carbon to volume relationships in dinoflagellates and other protists. Although these relationships also include species like $S$. trochoidea, estimated cell volumes based on measured POC quota were significantly overestimated for our species, as shown as an example for G. spinifera in Fig. 4.

As mentioned by Menden-Deuer and Lessard (2000), dinoflagellates have significantly higher carbon contents per volume than e.g. diatoms. For some dinoflagellate species, the carbon density may be even higher and result in the overestimation. Deriving a carbon to volume relationship specific for certain dinoflagellate species may solve the issue. In fact, microscopic measurements of some of the here tested species suggest that cell size is directly proportional to POC quota (radius $(\mu \mathrm{m}) \sim$ POC quota $^{1 / 3}(\mathrm{pg} \mathrm{C}$ $\mathrm{cell}^{-1}$; Fig. 4)). Consequently, such simple relationships may be applied for reconstructing POC quota based on cell volume. A complicating factor is the relationship between size of cells, as described here, and the size of cysts, found in the sedimentary records. Further work on the relationship between cell size and cyst size is required to better assess POC quota during ${ }^{13} \mathrm{C}$ fractionation. Alternatively, large cysts, i.e. large cells with an extraordinarily high POC quota, as found in the $1200 \mu \mathrm{atm} p \mathrm{CO}_{2}$ treatment of G. spinifera (Table 1), could be excluded from paleoreconstructions. As POC quota of all other tested species were in a range between $\sim 2000$ and $4000 \mathrm{pg} \mathrm{C}$ cell $^{-1}$ (Table 1), cells with extraordinarily high carbon contents $(\sim 8000 \mathrm{pg}$ $\mathrm{C} \mathrm{cell}^{-1}$ and bigger) may relatively easily be identified.

Although the experiments presented here suggest a rather negligible influence of growth rates on ${ }^{13} \mathrm{C}$ 


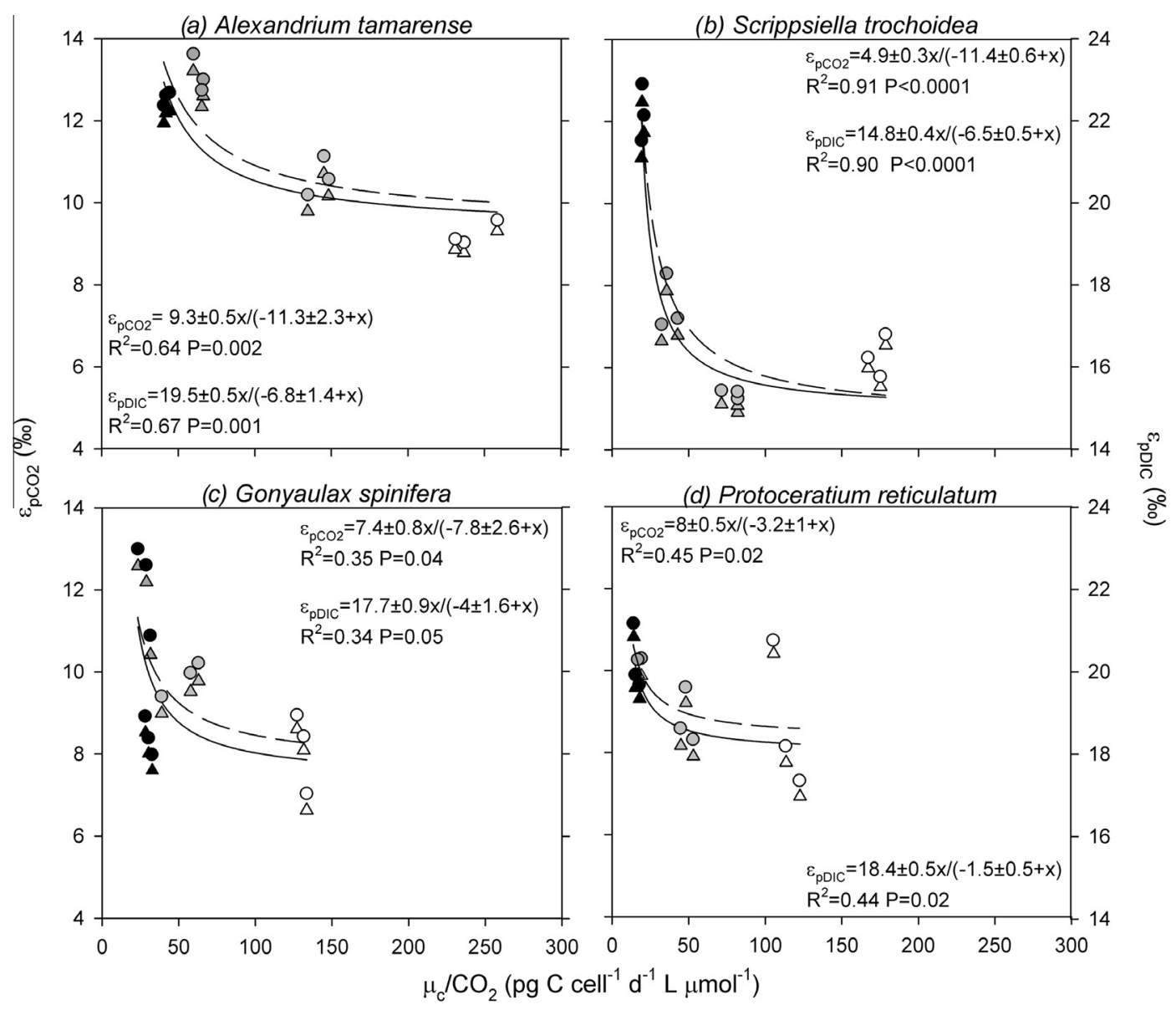

Fig. 3. ${ }^{13} \mathrm{C}$ fractionation based on $\mathrm{CO}_{2}\left(\varepsilon_{\mathrm{pCO}}\right.$, triangles $)$ and $\mathrm{DIC}\left(\varepsilon_{\mathrm{pDIC}}\right.$, circles $)$ of the studied dinoflagellates as a function of $\mu_{\mathrm{c}} / \mathrm{CO}_{2}$, and the respective hyperbolic relationships. Trend lines represent relationships between $\varepsilon_{\mathrm{pCO}_{2}}$ and $\mu_{\mathrm{c}} / \mathrm{CO}_{2}$ (solid line) and $\varepsilon_{\mathrm{pDIC}}$ and $\mu_{\mathrm{c}} / \mathrm{CO}_{2}$ (dashed line). Various $p \mathrm{CO}_{2}$ treatments are indicated by open $(180 \mu \mathrm{atm})$, light gray $(380 \mu \mathrm{atm})$, dark gray $(800 \mu \mathrm{atm}) \mathrm{and} \mathrm{black}(1200 \mu \mathrm{atm})$ symbols. The combination of analytical errors approximates $3 \%$ for ${ }^{13} \mathrm{C}$ fractionation and $8 \%$ for $\mu_{\mathrm{c}} / \mathrm{CO}_{2}$. Symbols show biological triplicates for each treatment. Treatment means and standard deviations are provided in Table 1.

fractionation (cf. Figs. 2c and 3c), their potential influence must be tested further. For instance, higher temperatures may lead to changes in growth rates that will depend on the species-specific growth optima, while limitation by resources, for example light, may cause a decrease in growth rate. This is especially important since other studies have shown that environmental factors, including light availability, affect ${ }^{13} \mathrm{C}$ fractionation in diatoms, a haptophyte, as well as a dinoflagellate species (Burkhardt et al., 1999b; Rost et al., 2002). Taking potential influences of growth rates on ${ }^{13} \mathrm{C}$ fractionation into account, estimations could be made by preferentially choosing those study sites for paleoreconstructions, where oceanographic settings stayed relatively constant throughout the past.

The observed species-specific differences illustrate the complexity and variety of physiological processes affecting ${ }^{13} \mathrm{C}$ fractionation. In fact, the use of multiple species in eventual proxy application could circumvent potential biases caused by the influence of environmental factors as light, nutrients and temperature. Additionally, the morphology of the cysts produced by dinoflagellates is highly species-specific so that species-specific calibrations can be confidently used to calculate paleo $p \mathrm{CO}_{2}$. Approximately $15 \%$ of the modern dinoflagellate species produce resting cysts (dinocysts), mainly during the sexual life cycle (Fensome et al., 1993). Sexual reproduction and subsequent cyst formation is usually triggered when dinoflagellates grow under nutrient (e.g. nitrogen or phosphorus) depletion at the end of blooms (Ellegaard et al., 1998; Rochon et al., 2009) and can happen rapidly within few minutes to an hour (Kokinos and Anderson, 1995; Hallet, 1999; Rochon et al., 2009). Most species produce cysts of organic matter, which are not susceptible to dissolution and very resistant to oxidation relative to other organic substrates. Consequently, dinocysts are typically found in sediments that are not completely oxidized. Dinocysts are found in sediments as old as the Triassic ( $\sim 215 \mathrm{Ma})$ and have provided valuable biostratigraphic tools and paleoenvironmental proxies on geological timescales (MacRae et al., 1996; Sluijs et al., 2005). Furthermore, cysts of many dinoflagellate species, including the ones of $G$. spinifera and $P$. reticulatum, can be found in sediments of very different oceanographic settings; i.e., they have a high tolerance for a range of nutrient concentrations and temperatures and 


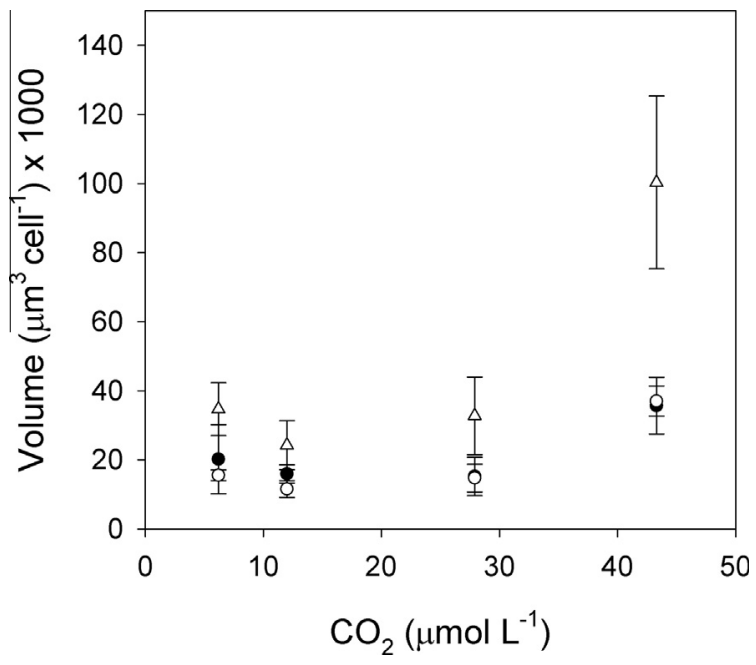

Fig. 4. Cell volumes of $G$. spinifera calculated based on microscope measurements (black circles; $n=10-15 ; \pm \mathrm{SD}$ ), calculated based on the simple relationship between POC quota and cell volume, which is described by a simple POC quota to volume relationship (open circles; $n=3 ; \pm \mathrm{SD}$ ), and averages of all relationships between POC quotas and cell volumes that are provided by Menden-Deuer and Lessard, (2000; open triangles; $n=6 ; \pm \mathrm{SD}$ ).

can thus be considered as cosmopolitan (Zonneveld et al., 2013). As they range in size between 20 and $150 \mu \mathrm{m}$, individuals can be identified and readily isolated to the biological species level using light microscopy. Finally, dinocysts contain sufficient carbon to determine their ${ }^{13} \mathrm{C}$ fractionation, in principle, on single cysts to few individuals.

Although cyst formation and early diagenesis (Zonneveld et al., 2008; Versteegh et al., 2010) may affect the $\delta^{13} \mathrm{C}$ of dinocysts, sedimentary studies have shown that dinocyst $\delta^{13} \mathrm{C}$ is related to the isotopic composition of dissolved inorganic carbon in seawater $\left(\delta^{13} \mathrm{C}_{\text {DIC }}\right.$; Sluijs et al., 2007). Cyst formation in controlled growth experiments and core top calibrations are needed to further constrain the relation between $p \mathrm{CO}_{2}$, dinoflagellate ${ }^{13} \mathrm{C}$ fractionation and dinocyst $\delta^{13} \mathrm{C}$. Atmospheric $p \mathrm{CO}_{2}$ changed considerably over geological timescales, varying between $180 \mu \mathrm{atm}$ to several thousands of $\mu$ atm (e.g. Petit et al., 1999; Zhang et al., 2001; Berner, 2006; Royer, 2006). Several proxies based on different organisms, shells and even mineral occurrences have been suggested for quantitative $\mathrm{CO}_{2}$ reconstructions (e.g. Eugster, 1966; Van Der Burgh et al., 1993; Jasper et al., 1994; Sanyal et al., 1996; Bidigare et al., 1997; Lowenstein and Demicco, 2006). Since available proxies are affected by factors other than $\mathrm{CO}_{2}$, the quest for additional constraints on past $p \mathrm{CO}_{2}$ remains important.

\section{CONCLUSIONS}

Dilute batch experiments have been performed with four dinoflagellate species in order to quantify the relationship between their ${ }^{13} \mathrm{C}$ fractionation and $\mathrm{CO}_{2}$ concentrations. Clear relationships between ${ }^{13} \mathrm{C}$ fractionation and $\mathrm{CO}_{2}$ concentrations were found for all tested species. However, an offset was found for the highest $p \mathrm{CO}_{2}$ treatment of $G$. spinifera, when cells exhibiting extraordinarily high POC quota yielded very low fractionation factors. Apparently, changing cellular organic carbon content (POC quota) relates to ${ }^{13} \mathrm{C}$ fractionation in G. spinifera to a greater extent than variations in growth rate. These results may be interpreted as a first step towards a proxy for past $p \mathrm{CO}_{2}$ based on carbon isotope ratios of fossil organic dinoflagellate cysts, although a suite of biological and biogeological experiments are required to establish a reliable proxy.

\section{ACKNOWLEDGMENTS}

This research was funded through Darwin Centre for Biogeosciences Grant 3021, awarded to GJR and AS, and the European Research Council under the European Community's Seventh Framework Program through ERC Starting Grants \#259627 to AS and \#205150 to BR. DBvdW and BR thank BIOACID, financed by the German Ministry of Education and Research. We thank Urban Tillmann (Alfred Wegener Institute) and Karin Zonneveld (Marum, Bremen University) for providing dinoflagellate strains Alex5 and GeoB 267, respectively, and Ulrike Richter, Laura Wischnewski, Jana Hölscher (Alfred Wegener Institute) and Arnold van Dijk (Utrecht University) for technical support.

\section{REFERENCES}

Barlow R. J. (1989) Statistics: a guide to the use of statistical methods in the physical sciences. John Wiley \& Sons.

Berner R. A. (2006) GEOCARBSULF: a combined model for Phanerozoic atmospheric $\mathrm{O}_{2}$ and $\mathrm{CO}_{2}$. Geochim. Cosmochim. Acta 70, 5653-5664.

Bidigare R. R., Fluegge A., Freeman K. H., Hanson K. L., Hayes J. M., Hollander D., Jasper J. P., King L. L., Laws E. A., Milder J., Millero F. J., Pancost R., Popp B. N., Steinberg P. A. and Wakeham S. G. (1997) Consistent fractionation of ${ }^{13} \mathrm{C}$ in nature and in the laboratory: growth-rate effects in some haptophyte algae. Glob. Biogeochem. Cycles 11, 279-292.

Boller A. J., Thomas P. J., Cavanaugh C. M. and Scott K. M. (2011) Low stable carbon isotope fractionation by coccolithophore RubisCO. Geochim. Cosmochim. Acta 75(22), 72007207

Burkhardt S., Riebesell U. and Zondervan I. (1999a) Effects of growth rate, $\mathrm{CO}_{2}$ concentration, and cell size on the stable carbon isotope fractionation in marine phytoplankton. Geochim. Cosmochim. Acta 63, 3729-3741.

Burkhardt S., Riebesell U. and Zondervan I. (1999b) Stable carbon isotope fractionation by marine phytoplankton in response to daylength, growth rate, and $\mathrm{CO}_{2}$ availability. Mar. Ecol. Prog. Ser. 184, 31-41.

Christeller J. T., Laing A. and Troughton J. H. (1976) Isotope discrimination by ribulose 1,5-diphosphate carboxylase. No effect of temperature or $\mathrm{HCO}_{3}^{-}$concentration. Physiol. Plant. 57(4), 580-582.

Dickson A. G. and Millero F. J. (1987) A comparison of the equilibrium constants for the dissociation of carbonic acid in seawater media. Deep-Sea Res. Pt. I - Oceanographic Res. Papers 34, 1733-1743.

Dickson A. G. (1990) Standard potential of the reaction: silver chloride + hydrogen $\left[\mathrm{AgCl}(\mathrm{s})+1 / 2 \mathrm{H}_{2}(\mathrm{~g})=\mathrm{Ag}(\mathrm{s})+\mathrm{HCl}(\mathrm{aq})\right]$, and the standard acidity constant of the ion $\mathrm{HSO}_{4}^{-}$in synthetic seawater from 273.15 to 318.15 K. J. Chem. Thermodyn. 22(2), $113-127$. 
Degens E.T., Behrendt M., Gotthardt B. and Reppmann E. (1968) Metabolic fractionation of carbon isotopes in marine plankton-II. Data on samples collected off the coasts of Peru and Ecuador. Deep Sea Research and Oceanographic 15(1), pp. 1120 (Deep Sea Research and Oceanographic Abstracts).

Eberlein T., Van de Waal D. B. and Rost B. (2014) Differential effects of ocean acidification on carbon acquisition in two bloom-forming dinoflagellate species. Physiol. Plant. 151(4), 468-479.

Eichner M., Thoms S., Kranz S. A. and Rost B. (2014) Cellular inorganic carbon fluxes in Trichodesmium: a combined approach using measurements and modelling. J. Exp. Bot. 427.

Egleston E. S., Sabine C. L. and Morel F. M. (2010) Revelle revisited: buffer factors that quantify the response of ocean chemistry to changes in DIC and alkalinity. Glob. Biogeochem. Cycles 24(1).

Ellegaard M., Kulis D. M. and Anderson D. M. (1998) Cysts of Danish Gymnodinium nolleri Ellegaard et Moestrup sp. ined. (Dinophyceae): studies on encystment, excystment and toxicity. J. Plankton Res. 20(9), 1743-1755.

Eppley R. W. (1972) Temperature and phytoplankton growth in the sea. Fish Bull. 70, 1063-1085.

Eugster H. P. (1966) Sodium carbonate-bicarbonate minerals as indicators of $p \mathrm{CO}_{2}$. J. Geophys. Res. 71, 3369-3377.

Fensome R. A., Taylor F. J. R., Norris G., Sarjeant W. A. S., Wharton D. I. and Williams G. L. (1993) A Classification of Modern and Fossil Dinoflagellates. Micropaleontology, Special Publication 7. Sheridan Press, Hanover, 351.

Francois R., Altabet M. A., Goericke R., McCorkle D. C., Brunet C. and Poisson A. (1993) Changes in the ${ }^{13} \mathrm{C}$ of surface water particulate organic matter across the subtropical convergence in the SW Indian ocean. Glob. Biogeochem. Cycles 7(3), 627-644.

Freeman K. H. and Hayes J. M. (1992) Fractionation of carbon isotopes by phytoplankton and estimates of ancient $\mathrm{CO}_{2}$ levels. Glob. Biogeochem. Cycles 6, 185-198.

Fry B. and Wainright S. C. (1991) Diatom sources of ${ }^{13} \mathrm{C}$-rich carbon in marine food webs. Mar. Ecol. Prog. Ser. 76, 149-157.

Guillard R. R. L. and Ryther J. H. (1962) Studies of marine planktonic diatoms. I. Cyclotella nana Hustedt and Detonula confervacea (Cleve). Gran Can. J. Microbiol. 8, 229-239.

Guy R. D., Fogel M. L. and Berry J. A. (1993) Photosynthetic fractionation of the stable isotopes of oxygen and carbon. Plant Physiol. 101(1), 37-47.

Hallett R. I. (1999) Consequences of environmental change on the growth and morphology of Lingulodinium polyedrum (Dinophyceae) in culture. Doctoral dissertation, University of Westminster.

Hinga K. R., Arthur M. A., Pilson M. E. and Whitaker D. (1994) Carbon isotope fractionation by marine phytoplankton in culture: the effects of $\mathrm{CO}_{2}$ concentration, $\mathrm{pH}$, temperature, and species. Glob. Biogeochem. Cycles 8(1), 91-102.

Jasper J. P., Hayes J. M., Mix A. C. and Prahl F. G. (1994) Photosynthetic fractionation of ${ }^{13} \mathrm{C}$ and concentrations of dissolved $\mathrm{CO}_{2}$ in the central equatorial Pacific during the last 255,000 years. Paleoceanography 9, 781-798.

Keller M. D., Selvin R. C., Claus W. and Guillard R. R. L. (1987) Media for the culture of oceanic ultraplankton. J. Phycol. 23, 633-638.

Kokinos J. P. and Anderson D. M. (1995) Morphological development of resting cysts in cultures of the marine dinoflagellate Lingulodinium polyedrum (= L. machaerophorum). Palynology 19(1), 143-166.

Laws E. A., Popp B. N., Bidigare R. R., Kennicut M. C. and Macko S. A. (1995) Dependence of phytoplankton carbon isotopic composition on growth rate and $\left[\mathrm{CO}_{2}\right]_{\mathrm{aq}}$ : theoretical considerations and experimental results. Geochim. Cosmochim. Acta 59, 1131-1138.

Laws E. A., Bidigare R. R. and Popp B. N. (1997) Effect of growth and $\mathrm{CO}_{2}$ concentration on carbon isotope fractionation by the marine diatom Phaedactylum tricornutum. Limnol. Oceanogr. 42, 1552-1560.

Lewis E. and Wallace D. W. R. (2006) Program developed for $\mathrm{CO}_{2}$ system calculations. Carbon Dioxide Information Analysis Center, Oak Ridge National Laboratory. Available at: http:// cdiac.ornl.gov/oceans/co2rprt.html.

Lowenstein T. K. and Demicco R. V. (2006) Elevated eocene atmospheric $\mathrm{CO}_{2}$ and its subsequent decline. Science 313, 1928.

MacRae R. A., Fensome R. A. and Williams G. L. (1996) Fossil dinoflagellate diversity, originations and extinctions and their significance. Can. J. Bot. 74, 1687-1694.

McNevin D. B., Badger M. R., Whitney S. M., von Caemmerer S., Tcherkez G. G. and Farquhar G. D. (2007) Differences in carbon isotope discrimination of three variants of d-ribulose1,5-bisphosphate carboxylase/oxygenase reflect differences in their catalytic mechanisms. J. Biol. Chem. 282(49), 3606836076.

Mehrbach C., Culberson C. H., Hawley J. E. and Pytkowicz R. M. (1973) Measurement of the apparent dissociation constants of carbonic acid in seawater at atmospheric pressure. Limnol. Oceanogr. 18, 897-907.

Menden-Deuer S. and Lessard E. J. (2000) Carbon to volume relationships for dinoflagellates, diatoms, and other protist plankton. Limnol. Oceanogr. 45, 569-579.

Mook W. G., Bommerson J. C. and Staverman W. H. (1974) Carbon isotope fractionation between dissolved bicarbonate and gaseous carbon dioxide. Earth Planet. Sci. Lett. 22, 169 176.

Pagani M., Freeman K. H., Ohkouchi N. and Caldeira K. (2002) Comparison of water column $\left[\mathrm{CO}_{2}\right]_{\mathrm{aq}}$ with sedimentary alkenone-based estimates: a test of the alkenone- $\mathrm{CO}_{2}$ proxy. Paleoceanography 17, 609-632.

Pagani M. (2002) The alkenone- $\mathrm{CO}_{2}$ proxy and ancient atmospheric carbon dioxide. Philos. Trans. R. Soc. Lond. Ser. A: Math. Phys. Eng. Sci. 360(1793), 609-632.

Pagani M. (2014) Biomarker-based inferences of past climate: The alkenone $p \mathrm{CO}_{2}$ proxy. Treatise on Geochemistry 2 nd edition.

Petit J. R., Jouzel J., Raynaud D., Barkov N. I., Barnola J. M., Basile I., Bender M., Chappellaz J., Davis M., Delaygue G., Delmotte M., Kotlyakov V. M., Legrand M., Lipenkov V. Y., Lorius C., Pépin L., Ritz C., Saltzman E. and Stievenard M. (1999) Climate and atmospheric history of the past 420,000 years from the Vostok ice core, Antarctica. Nature 399(6735), 429-436.

Popp B. N., Laws E. A., Bidigare R. R., Dore J. E., Hanson K. L. and Wakeham S. G. (1998) Effect of phytoplankton cell geometry on carbon isotopic fractionation. Geochim. Cosmochim. Acta 62, 69-77.

Popp B. N., Parekh P., Tilbrook B., Bidigare R. R. and Laws E. A. (1997) Organic carbon $\delta^{13} \mathrm{C}$ variations in sedimentary rocks as chemostratigraphic and paleoenvironmental tools. Paleogeograph. Paleoclimatol. Paleoecol. 132, 119-132.

Ratti S., Giordano M. and Morse D. (2007) $\mathrm{CO}_{2}$-concentrating mechanisms of the potentially toxic dinoflagellate Protoceratium reticulatum (Dinophyceae, Gonyaulacales). J. Phycol. 43, 693-701.

Rau G. H., Riebesell U. and Wolf-Gladrow D. A. (1996) A model of photosynthetic ${ }^{13} \mathrm{C}$ fractionation by marine phytoplankton based on diffusive molecular $\mathrm{CO}_{2}$ uptake. Mar. Ecol. Prog. Ser. 133, 275-285.

Raven J. A. and Johnston A. M. (1991) Mechanisms of inorganiccarbon acquisition in marine phytoplankton and their 
implications for the use of other resources. Limnol. Oceanogr. 36, 1701-1714.

Riebesell U., Revill A. T., Holdsworth D. G. and Volkman J. K. (2000) The effects of varying $\mathrm{CO}_{2}$ concentration on lipid composition and carbon isotope fractionation in Emiliania huxleyi. Geochim. Cosmochim. Acta 64, 4179-4192.

Rochon A., Lewis J., Ellegaard M. and Harding I. C. (2009) The Gonyaulax spinifera (Dinophyceae) "complex": perpetuating the paradox? Rev. Palaeobot. Palyno. 155(1), 52-60.

Roeske C. A. and O'Leary M. H. (1984) Carbon isotope effects on enzyme-catalyzed carboxylation of ribulose bisphosphate. Biochemistry 23(25), 6275-6284.

Roeske C. A. and O'Leary M. H. (1985) Carbon isotope effect on carboxylation of ribulose bisphosphate catalyzed by ribulose bisphosphate carboxylase from Rhodospirillum rubrum. Biochemistry 24(7), 1603-1607.

Rost B., Zondervan I. and Riebesell U. (2002) Light-dependent carbon isotope fractionation in the coccolithophorid Emiliania huxleyi. Limnol. Oceanogr. 47, 120-128.

Rost B., Richter K.-U., Riebesell U. and Hansen P. J. (2006) Inorganic carbon acquisition in red tide dinoflagellates. Plant Cell Environ. 29, 810-822.

Royer D. L. (2006) $\mathrm{CO}_{2}$-forced climate thresholds during the Phanerozoic. Geochim. Cosmochim. Acta 70, 5665-5675.

Sanyal A., Hemming N. G., Broecker W. S., Lea D. W., Spero H. J. and Hanson G. N. (1996) Oceanic pH control on the boron isotopic composition of foraminifera: evidence from culture experiments. Paleoceanography 11, 513-517.

Scott K. M., Henn-Sax M., Harmer T. L., Longo D. L., Frame C. H. and Cavanaugh C. M. (2007) Kinetic isotope effect and biochemical characterization of form IA RubisCO from the marine cyanobacterium Prochlorococcus marinus MIT9313. Limnol. Oceanogr. 52(5), 2199-2204.

Sharkey T. D. and Berry J. A. (1985) Carbon isotope fractionation of algae as influenced by an inducible $\mathrm{CO}_{2}$ concentrating mechanism. In Inorganic carbon uptake by aquatic photosynthetic organisms (eds. W. J. Lucas and J. A. Berry). The American Society of Plant Physiologists 389-401.

Sluijs A., Pross J. and Brinkhuis H. (2005) From Greenhouse to icehouse; organic-walled dinoflagellates as paleoenvironmental indicators in the Paleogene. Earth Sci. Rev. 68, 281-315.

Sluijs A., Brinkhuis H., Schouten S., Bohaty S. M., John C. M., Zachos J. C., Reichart G.-J., Sinninghe-Damsté J. S., Crouch E. M. and Dickens G. R. (2007) Environmental precursors to rapid light carbon injection at the Paleocence/Eocene boundary. Nature 450, 1218-1221.

Tillmann U., Alpermann T. L., da Purificação R. C., Krock B. and Cembella A. (2009) Intra-population clonal variability in allelochemical potency of the toxigenic dinoflagellate Alexandrium tamarense. Harmful Algae 8, 759-769.

Van Der Burgh J., Visscher H., Dilcher D. L. and Kürschner W. M. (1993) Paleoatmospheric signatures in Neogene fossil leaves. Science 260, 1788-1790.

Van de Waal D. B., John U., Ziveri P., Reichart G.-J., Hoins M., Sluijs A. and Rost B. (2013) Ocean acidification reduces growth and calcification in a marine dinoflagellate. PLOS ONE 8(6). http://dx.doi.org/10.1371/journal.pone.0065987.

Versteegh G. J., Zonneveld K. A. and de Lange G. J. (2010) Selective aerobic and anaerobic degradation of lipids and palynomorphs in the Eastern Mediterranean since the onset of sapropel S1 deposition. Mar. Geol. 278(1), 177-192.

Zhang J., Quay P. D. and Wilbur D. O. (1995) Carbon isotope fractionation during gas-water exchange and dissolution of $\mathrm{CO}_{2}$. Geochim. Cosmochim. Acta 59, 107-114.

Zhang Y. G., Pagani M., Liu Z., Bohaty S. M. and DeConto R. (2001) A 40-million-year history of atmospheric $\mathrm{CO}_{2}$. Philos. Trans. R. Soc. A: Math. Phys. Eng. Sci. 371(2001).

Zeebe R. E. and Wolf-Gladrow D. A. (2001) $\mathrm{CO}_{2}$ in seawater: equilibrium, kinetics, isotopes. Elsevier Science, Amsterdam, The Netherlands.

Zonneveld K. A., Versteegh G. and Kodrans-Nsiah M. (2008) Preservation and organic chemistry of Late Cenozoic organicwalled dinoflagellate cysts: a review. Mar. Micropaleontol. 68(1), 179-197.

Zonneveld K. A., Marret F., Versteegh G. J., Bogus K., Bonnet S., Bouimetarhan I., Crouch E., de Vernal A., Elshanawany R., Edwards L., Esper O., Forke S., Grøsfjeld K., Henry M., Holzwarth U., Kielt J.-F., Kim S.-Y., Ladouceur S., Ledu D., Chen L., Limoges A., Londeix L., Lu S.-H., Mahmoud M. S., Marino G., Matsuoka K., Matthiesen J., Mildenthal D. C., Mudie P., Neil H. L., Pospelova V., Qi Y., Radi T., Richerol T., Rochon A., Sangiorgi F., Solignac S., Turon J.-L., Verleye T., Wang Y., Wang Z. and Young M. (2013) Atlas of modern dinoflagellate cyst distribution based on 2405 data points. Rev. Palaeobot. Palyno. 191, 1-197. 